\title{
An Empirical Capital Market Rate Function for South Africa
}

\author{
Elna Pretorius and Charlotte du Toit
}

Department of Economics, University of Pretoria

\begin{abstract}
The aim of this paper is to explain the determinants of the South African longterm interest rate. A market-related approach is followed which explains interest rate determination on the basis of the relationships between the capital market and other domestic and international markets. Some implications for monetary policy are derived.
\end{abstract}

JEL G 12

\section{INTRODUCTION}

Interest rates are the key determinants in the flow of funds from the financial sector to particular real investments in the real sector of the economy. If the markets operate efficiently, funds flow to the most economically attractive real investment opportunities, where attractiveness is determined by the interest rate offered and the probability of being repaid. In practice, money flows in large amounts from lenders to different borrowers on the basis of fairly small changes in interest rates. Relatively small changes in interest rates can therefore cause huge flows of money from one sector to another. These flows, in turn, can be a major determinant of the amount of real economic activity that takes place and in what sectors growth occurs. Even a percentage point increase can have a huge impact on the present discounted value of future revenues, and thus on investment decisions, output and jobs (Smith \& Spudeck, 1993: 14). Interest rates are therefore a vital part of the economy, and knowledge of the role of interest rates and the reasons underlying their movements is crucial to an understanding of financial developments and economic policy.

Monetary authorities are particularly interested in the determination of the longterm interest rate and wish to understand to what extent they can influence it. In South Africa the Reserve Bank plays a vital role in determining the level of short-term interest rates since these are closely related to the repo rate, which is the interest rate at which the Reserve Bank lends money to commercial banks. However, monetary authorities do not know whether, and to what extent, they 
can influence the long-term interest rate. The aim of this paper is to determine the factors underlying changes in the long-term interest rates in South Africa, with specific reference to the implications for monetary policy.

Apart from analysing the univariate characteristics of the data and empirically estimating the factors that influence the interest rate and the magnitudes of these influences, the estimated function is subjected to rigorous diagnostic and stability testing. The estimated function can be used to forecast the long-run level of South African interest rates, and will form the linkage between the real and financial sectors in the macroeconometric model of the Department of Economics, University of Pretoria.

\section{THE SOCIO-POLITICAL ENVIRONMENT IN SOUTH AFRICA}

The course of South African interest rates could be influenced by the different phases of monetary policy and the dramatic socio-political changes in the country. Since the empirical function will be estimated for the period 1960 to 1998 , the discussion will also be confined to this period.

During the 1960s, the South African Reserve Bank attempted to slow down an excessive expansion of liquidity in the banking sector by introducing a required liquid asset ratio in the Banks Act of 1965. After the promulgation of the Banks Act, there were years of brisk economic activity, increasing inflationary pressures and a rapidly expanding liquidity base of the banking system. During his tenure, Dr De Jongh (Reserve Bank Governor from 1967 to 1980) implemented a series of additional direct controls such as a ceiling on advances, deposit rate controls, exchange control, import deposits and some direct consumer credit controls in an effort to contain the persistent increases in money supply and the inflationary tendency. The results were encouraging, and the country enjoyed high levels of real growth.

The controls of the 1960 s and 1970 s gave way in the 1980 s to a general recognition of the need to abolish as many restrictions as possible in a shift to market-oriented policy. This was in line with the international thinking of the time. During the $1980 \mathrm{~s}$, there was a definite shift across the globe in favour of market-oriented policy measures. This shift in policy was further encouraged by the liberalisation of international financial markets. South Africa likewise followed this pattern, and under Dr De Kock (Reserve Bank Governor from 1981 to 1989), the Reserve Bank became more willing to align its policies to market developments, rather than to try to force markets in a certain direction. This was the most difficult decade in the history of the Reserve Bank, operating as it did in the face of widespread international hostility and growing resistance 
to the consequences of the economic and racial policies of the government at the time. After President PW Botha's so-called Rubicon speech, international sanctions and a debt boycott were introduced against South Africa, and huge amounts of capital flowed out of the country almost immediately. This period of international isolation was characterised by high interest rates that attempted to prevent capital outflow and attract foreign capital. (Botha, 1997; Fourie et al., 1999: 314).

Although monetary policy did not change much in the 1990 s - the Stals era some most dramatic changes in the socio-political situation occurred during this period. After the first democratic election in 1994, political barriers were removed and South Africa became more exposed to world financial market movements, as a result of the abolition of sanctions and the scrapping of exchange controls on foreigners. Since 1994 in particular, South Africa has adopted a clearly defined policy of actively participating in the process of financial globalisation and implemented a number of economic policies to facilitate its participation in globalisation (Stals, 1999).

Financial globalisation caused revolutionary and irreversible changes in capital markets. International capital transactions have accelerated and international financial interdependence increased substantially. Innovation and deregulation have changed financial market structures. More instruments and markets have developed, and technological change has made portfolios comprising international assets universal. As a consequence of these transformations, financial markets have become more efficient, but also more volatile and subject to speculation. Some countries benefit greatly from the opportunity to attract unprecedented inflows of capital. However, international markets tend to shun countries that are not performing well. It is therefore not surprising that subSaharan Africa, the region with the world's poorest growth record, is now a net exporter of capital. Furthermore, capital flight is increasingly prevalent in countries that are perceived not to provide competitive investment opportunities. The international environment has simply become much more averse to countries that do not foster competitive economies (Handley \& Mills, 1996: 74).

In broad, monetary policy in South Africa since the 1960 s can thus be divided into the pre-1985 and post-1985 periods, with a shift from the use of direct monetary instruments to more market-oriented monetary policy. This dramatic policy shift implies that monetary variables such as interest rates will contain a structural break, which should be reflected in the empirical estimation of such a variable. The most significant socio-political events that impacted on the course of South African interest rates, international sanctions and the process of 
financial globalisation, also have to be reflected in the empirical estimation of interest rates.

\section{THE SOUTH AFRICAN CAPITAL MARKET}

The capital market constitutes the long-term component of the financial system, and can be regarded as the complex structure of institutions and mechanisms involved in the trade of long-term securities (with maturity longer than one year) (Fourie, Falkena \& Kok, 1999: 183). It is not a physical market, but only the abstract concept that includes all trade in long-term securities in the same way that the money market includes all trade in short-term securities (Stapelberg, 1981: 23). The capital market can be broadly divided into two parts, namely the primary and the secondary market. New securities are issued in the primary market, while previously issued securities are traded in the secondary market.

\subsection{The primary capital market}

Securities are issued in the primary market by institutions wishing to borrow money. Securities are issued in South Africa by the Treasury, public corporations (e.g. Eskom), public utilities (e.g. Telkom and Transnet), local authorities and private sector companies when they need to finance their activities. The demand for the securities issued in the primary capital market is generally by banks, building societies, insurance companies, pension funds, mining houses, stockbrokers, and the Public Investment Commissioners (Fourie et al., 1992: 121).

The securities issued in the primary market can be either fixed- or variableinterest-bearing securities. Fixed-interest-bearing securities such as government bonds, annuities and debentures are characterised by a stipulated maturity date and value (the nominal or face value) and contractually guaranteed interest payments. These interest payments are based on a fixed and predetermined rate (the coupon rate) paid on the nominal value of the bond (Fourie et al., 1999: 172). If the security is issued at nominal value, its yield will be equal to this rate of interest, since the interest payment will be the only income received from this investment. However, if the security is issued at a price below the nominal value, the yield to maturity will be higher than this rate of interest since the yield will not only include the interest receipts but also a capital gain. The interest rates on variable-interest securities (e.g. long-term loans), shares and negotiable documents fluctuate sharply, particularly when the inflation rate changes frequently. In South Africa, a variable-interest loan normally remains a contract solely between the lender and the borrower. 
The way in which securities are issued depends on the type of security. Government bonds are sold on a tap or tender basis. In the case of a tap issue, the Reserve Bank buys stock from the Treasury at a rate at which the Bank can sell a fairly large volume to the market, and then resell it to the public. In the case of a tender issue, the date of the issue and amount of stock available are announced to the public, and sold to the highest bidders. Other fixed-interest securities as well as all variable-interest securities are either sold by the issuer or by an underwriter, usually a merchant bank, acting on behalf of the issuer. The issue may either be by way of a public issue where the terms and conditions are announced to the public at large, or by way of a private issue where it is offered only to selected investors (Fourie et al., 1999: 185; Fabozzi, 1992: 523).

\subsection{The secondary capital market}

The securities issued in the primary market are traded in the secondary market. The financial intermediary sector is the principal supplier of funds to the secondary capital market, in particular insurers, pension funds and building societies, which simply channel surplus funds of the household sector into appropriate investments. Other banking institutions, the Public Investment Commissioners, and other financial intermediaries such as participation mortgage bond schemes and the National Housing Commission are also lenders in the capital market (Fourie et al., 1992: 41). The main traders of securities in the secondary capital market are divided into five categories, namely financial intermediaries, the government, corporate business enterprises, households and the foreign sector. Foreign participants, in other words foreign households, businesses, institutional investors and governments, act in the South African capital market in the same way as domestic households, businesses, investors and the government. However, technological development and the process of globalisation have dramatically increased the importance and role of foreign participants in the domestic capital and other financial markets. Globalisation has resulted in the acceleration of international capital transactions, and international financial interdependence has increased substantially. In consequence, financial markets have become more efficient, but also more volatile and subject to speculation practices. Advances in computer technology, coupled with advanced telecommunication systems, link market participants throughout the world and allow the transmission of real-time information on security prices and other key information to many participants in many places. This enables many investors to monitor global markets and simultaneously assess how this information will impact on the risk/reward profile of their portfolios (Fabozzi, 1995: 15).

The securities that are issued in the primary market are traded in the secondary market. The number of new securities issued in the primary market has a 
considerable influence on the demand for and price of securities in the secondary market. The secondary market serves as a barometer of changes in the markets and reflects these changes in the prices and volumes of traded securities. This gives the issuers in the primary market a good idea of the correct price and interest rate at which they should issue new securities which is vital to a successful issue. The secondary market also guarantees investors that they will be able to resell their securities and adjust their portfolios, provides an indication of the general availability of funds and enables the Reserve Bank to buy and sell securities in order to influence the liquidity of financial markets (Fourie, 1999:13; Faure et al., 1991: 10).

There are active markets in many of the securities issued in the primary market, but they differ in terms of so-called "breadth" and "depth". Mainly fixedinterest-bearing securities are traded in the secondary market, while there is virtually no secondary market for variable-interest securities because of the uncertainty of their variable pattern of income which makes it difficult to discount their future eamings. Institutions trade in the secondary market in the attempt to maximise their expected portfolio returns while bearing minimum risk. Investment is therefore a risk-return trade-off.

The nominal rate of return (R) on a security is not the absolute rand return, but is calculated as $R=\frac{s_{1}-s_{0}+d}{s_{0}}$, where $s_{0}$ and $s_{J}$ are the price of the security at the beginning and the end of the investment and $d$, any dividends or interest payments in the interim (Kobold, 1986: 67). Since the rate of return is uncertain, the investor has to take into account the risk that the expected return may not be realised. Risk is the variation of actual return from expected return and may be caused by broad economic forces such as recession, unemployment and inflation, or attributable to causes that are peculiar to the specific security or issuing company. There are several risks associated with investing in bonds. Interest-rate risk is the risk that if an investor has to sell a bond prior to the maturity date, an increase in interest rates will mean a capital loss (Fabozzi \& Modigliani, 1996: 5). Reinvestment risk is the variability in the reinvestment rate of a given strategy because of changes in market interest rates (Fabozzi \& Modigliani, 1996: 5). Default or credit risk is the risk that the issuer of a bond may default, in other words be unable to make timely principal and interest payments on the issue. Inflation or purchasing power risk arises as a result of the variation in the value of cash flows from a security because of inflation, as measured in terms of purchasing power of money (Fabozzi \& Modigliani, 1996: 7). The risk that the currency in which the flows are paid will depreciate relative to the rand, is the exchange rate or currency risk (Fabozzi \& Modigliani, 1996: 7). Liquidity or marketability risk depends on the ease with which an issue can 
be sold at or near its value, usually measured by the size of the spread between the bid price and the ask price quoted by a dealer (Fabozzi \& Modigliani, 1996: 7).

Risk and return are always the criteria for investment, but investors can choose between the efficient market hypothesis (EMH), Markowitz's portfolio choice theory and the capital asset pricing model (CAPM) (Dobbins, Witt \& Fielding, 1994: 18). Security prices conform to the law of demand and the law of supply like any other price. Since the demand and supply of a security are determined by the behaviour of investors, their behaviour will also influence security prices and therefore interest rates.

\section{AN EMPIRICAL FUNCTION/MODEL FOR THE LONG-TERM INTEREST RATE}

In this section the determinants of the long-term interest rate are empirically estimated by means of annual data. Although the yield on the R150 long-term government bond is the leading long-term interest rate in South Africa, it was issued in 1987 and expires in 2004, which means that only a minute sample of 12 observations is currently available. The R150 yield is also extremely volatile, which makes empirical estimation rather difficult. Hence in this study the yield on the Eskom 168 (E168) security is used instead to proxy the general level of long-run interest rates in South Africa (see Figure 1).

The El68 is a security issued by Eskom. It has biannual interest payments fixed at 11 per cent on the nominal value, and it matures on 1 June 2008. Unlike the R150 and other government bonds, the government does not guarantee Eskom securities. The guarantee of Eskom securities lies in the size of Eskom, the fifth largest utility in the world, and the nature of its business, namely the provision of electricity to Southern Africa (http://www.eskom.co.za). Hence Eskom securities, like govemment bonds, are not subject to default risk. Since the E168 long-term Eskom security has no default risk, is actively traded in the South African capital market and a relatively large sample is available, it may be used to proxy long-term interest rates in South Africa. 


\section{Figure 1 The Eskom rate}

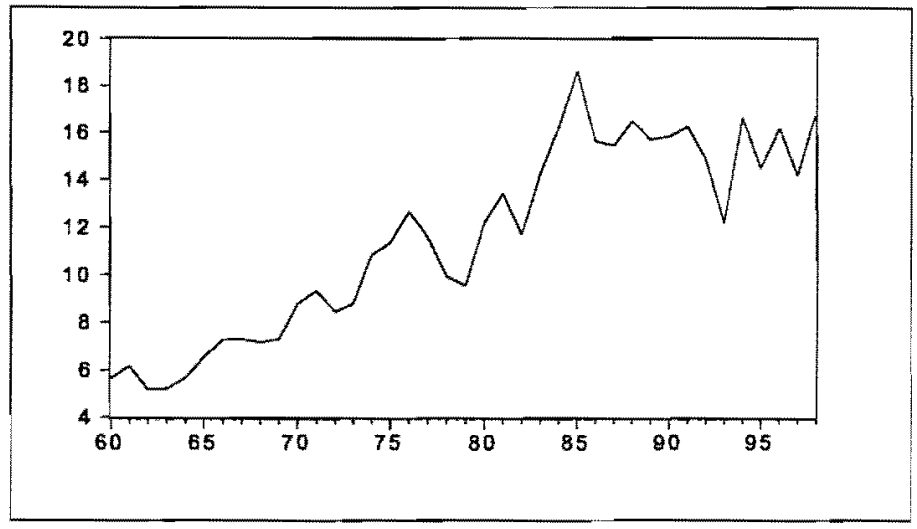

\subsection{The theoretical model}

The process of globalisation dramatically changed the way in which small open economies, such as South Africa, function. They no longer function in an isolated environment, for their financial markets are driven by developments in international markets. The market approach (see Gayed 1990 and Murphy 1991) is therefore regarded as the most appropriate analytical method in a small open economy where the interaction between the various domestic and international markets predominantly determines interest rates. Studies on interest rate determination in small open economies, such as Harmse and Du Toit (1999) and Hodgson, Kremmer and Lee (1998), are therefore based on the market approach, which explains interest rate determination on the basis of the relationship between the various domestic and international markets. On the other hand, interest rates in large economies are mainly determined by the traditional demand and supply factors. Studies such as Tran and Sawhney (1998), Mehra (1995) and Mehra (1994) on interest rate determination in industrialised countries are thus based on the economic approach which explains interest rate determination by the demand and supply of money or loanable funds. This study will however follow the market approach, since South Africa has a small open economy where interest rates are determined by movements in international and domestic markets.

A priori theory suggests the following about the relevant variables and their coefficients:

(i) The long-term interest rate should be positively related to international interest rates. As the South African financial markets become more 
integrated with the international financial system, the relationship between domestic and international interest rates becomes increasingly important. Domestic interest rates that are too low will eventually be reflected in a weak currency, and also cause further depreciation of the rand. Conversely, interest rates that are too high will encourage speculative short-term foreign capital that will cause undesirable appreciation of the currency and/or an unhealthy expansion of domestic liquidity (SARB, 1999). Various studies such as that of Pain and Thomas (1997), Hodgson, Kremmer and Lee (1998) and Awad and Goodwin, have shown that the US long-bond rate is the most influential in the world and can be regarded as the leading rate. It is also used in most studies of small open economies such as Harmse and Du Toit (1999) and Hodgson, Kremmer and Lee (1998) to represent the international level of interest rates. Hence in this study, the US long-bond rate is also used to represent the level of international interest rates.

(ii) The short-term interest rates are determined in the money market. If the long-term interest rate does not rise when the short-term interest rates rise, investors will substitute their long-term bonds for money market securities. An increase in the short-term rate should therefore cause an increase in the long-term rate.

(iii) According to the Fisher effect, the rate of inflation causes the nominal interest rate to change so that the real rate is unaffected by the rate of inflation. An increase in expected inflation should therefore result in a proportional increase in the nominal interest rate.

This results in the following specification for the interest rate function (See Appendix 2 for an explanation of the pneumonic variables):

$$
\begin{aligned}
& R L=f(U S, E(N F L), R S) \\
& (+++)
\end{aligned}
$$

\subsection{The data}

All the data were obtained from the Quarterly Bulletin of the South African Reserve Bank, except the US interest rate which was obtained from the International Financial Statistics of the Intemational Monetary Fund. All the variables were transformed into the natural logarithmic form. Annual data from 1960 to 1998 were used.

The yield on the E168 Eskom bond was used as the representative long-term interest rate in South Africa. The three-month banker's acceptance rate is 
considered to be the representative short-term interest rate and the yield on 30year US government bonds is used as the long-term interest rate of the USA. Kalman filter predictions of the expected one-period-ahead inflation rate were used as inflationary expectations. The specification, including the lagged inflation rate, interest rate and exchange rate, was based on the specification of Koekemoer (2000) for Kalman filter predictions of the expected one-periodahead price expectations. In the specification the rand-dollar exchange rate was used as the exchange rate, and the Eskom rate as the interest rate. A dummy variable was created to represent the years 1985 to 1990 during which there were international sanctions and disinvestment actions against South Africa. During this period, interest rates were kept at a high level in an attempt to prevent capital outflow and to attract foreign capital.

Models that contain potentially non-stationary variables can result in a spurious regression, indicating statistically significant relationships where there are none. The statistical significance obtained from standard regression techniques with non-stationary variables is picking up is the existence of contemporaneous correlation in the variables due to their trending over time, rather than a meaningful causal relationship between them. It is therefore vital to determine the order of integration of all the variables used in the econometric analysis, since this will determine the correct estimation technique to use. In this study, the augmented Dickey Fuller (ADF) (1979) and Phillips-Perron (PP) (1988) tests were used in conjunction with data plots to establish the order of integration of the variables. The ADF test assumes that the errors are statistically independent and have a constant variance, while the PP test allows the disturbances to be weakly dependent and heterogeneously distributed (Enders, 1995: 239). The PP test also has greater power to reject the false null hypothesis of a unit root, except when the errors have a moving average (MA) structure, in which case this test tends to reject the null hypothesis whether it is true or false. Since the structure of the error terms is usually unknown, it is preferable to use both tests. Hence both the augmented Dickey Fuller (ADF) and the PhillipsPerron (PP) tests were used in this study to establish the order of integration of the variables. When there are structural breaks, however, the ADF and PP test statistics are biased towards the non-rejection of a unit root, and the Perron (1989) test for unit roots in the presence of a structural break should be used instead (Enders, 1995: 261; Charemza \& Deadman, 1997: 119). Appendix 3 summarises the results of the unit root tests.

A priori theory suggests a possible structural break in South African long-term interest rate in 1985 when monetary policy changed dramatically from direct to market-oriented monetary instruments. The graph of the long-term interest rate series (see figure 1) confirms that a possible structural break occurred in 1985. The results of the ADF and PP test are invalidated by the occurrence of a 
structural break - hence the Perron test for testing unit roots in the presence of a structural break was used to test the stationarity of the Eskom series. The results, which are summarised in Appendix 3, confirm that the long-term interest rate is trend-stationary with a structural break in 1985.

Visual inspection of the graph of the long-term US interest rate (see Appendix 1) suggests a possible structural break. The Perron test for a unit root in the presence of a structural break confirms that the US long-term interest rate is in fact trend-stationary with a structural break (see Appendix 3).

The ADF and PP tests rejected the null hypothesis of a unit root against the alternative of trend stationarity for the short-term interest rate. Therefore, if a trend is included in the regression, the short-term interest rate can be directly included in the OLS-regression.

In contrast to a priori expectations, both the ADF and PP tests could not reject the null hypothesis of a unit root for the inflationary expectations in levels $(\mathrm{E}(\mathrm{INFL}))$. However, if there is a structural break in the inflation rate and inflationary expectations as suggested by the graphs, it invalidates the results of the ADF and PP tests. The results of the Perron test for unit roots in the presence of a structural break render expected inflation trend-stationary with a structural break in 1985. Inflationary expectations are therefore regarded as integrated of order zero.

\subsection{Empirical estimation of the long-term interest rate function for South Africa}

The dependent variable tested trend-stationary with a structural break in 1985 , which implies that ordinary least squares (OLS) is the appropriate technique to use, with a trend dummy (TIME) and a dummy allowing for the new trend (DT) included. With the trend and the new trend dummies included, the South African short-term and US long-term interest rates can be regarded as stationary and therefore included without any transformation.

Both the long-run equilibrium equation and the short-run dynamics or deviations from equilibrium are simultaneously included when OLS is used - in other words an ECM structure such as that of Mehra (1994), Mehra (1995) and Harmse and Du Toit (1999) is considered to be inappropriate in this context. 
Table 1 Estimation results of OLS-regression, dependent variable: SA long-term interest rate

\begin{tabular}{|l|c|c|c|r|}
\hline \multicolumn{1}{|c|}{ Variable } & Coefficient & $\begin{array}{c}\text { Standard } \\
\text { Error }\end{array}$ & t-value & p-values \\
\hline US & 0.225712 & 0.084908 & 2.658324 & 0.0125 \\
RS & 0.241269 & 0.047219 & 5.109571 & 0.0000 \\
TIME & 0.000491 & 0.036744 & 3.752138 & 0.0000 \\
DT & 0.020408 & 0.005954 & 3.427301 & 0.0018 \\
E(INFL) & 0.984009 & $5.35 E-05$ & 9.177556 & 0.0557 \\
DUM- & 0.165878 & 0.494351 & 1.990508 & 0.0004 \\
SANCT & 0.138707 & 0.041299 & 4.016492 & 0.0008 \\
RS(-2) & & & & DW $=1.9696$ \\
\hline Sample period (adjusted): 1964 to 1998 & & \\
$\bar{R}^{2}=0.9578$ & & & & \\
s.e. $=0.0756$ & &
\end{tabular}

With the natural logarithmic form, coefficients may be interpreted as elasticities. The coefficient of each explanatory variable can be interpreted as follows:

i) US long-term interest rate (US). A one per cent increase in the long-term interest rate of the US results in a 0.225712 per cent increase in the domestic (SA) long-term interest rate.

ii) Short-term interest rate (RS). A one per cent increase in the short-term interest rate results in a 0.241269 per cent increase in the long-term interest rate. Apart from this contemporaneous effect, a one per cent increase in the short-term interest rate two years ago will also cause a 0.138707 per cent increase in the current long-term interest rate. The short-term rate one period ago was insignificant.

iii) Inflationary expectations ((E(INFL)). A one per cent increase in the oneperiod-ahead inflationary expectations results in a 0.984009 per cent increase in the long-term interest rate. When the null hypothesis that the coefficient is not equal to one was tested against the alternative hypothesis that it is equal to one, it was rejected. The coefficient is therefore assumed to be one, which conforms to the a priori expectation.

iv) Sanctions (DUM-SANCT). During the period of sanctions against South Africa, interest rates were on average 0.165878 percentage points above the equilibrium path. This implies that South Africa was extremely sensitive to international sentiment at that time. 
v) Time trend (TIME). The coefficient of the trend in the equation is 0.000491 which means that the long-term interest rate grows on average by 0.000491 per cent every year.

vi) New trend (DT). The coefficient of the variable that measures the new trend after 1985 is 0.020408 , which means that the interest rate grows on average 0.020408 per cent faster than before.

\section{EVALUATION OF THE RESULTS}

\subsection{Economic evaluation of the estimated function}

Except for the coefficient of inflationary expectations that should be one, economic theory provides only a priori information on the sign of the coefficients and not on the size of the coefficients. As explained in section 4.1, the long-term US interest rate, the domestic short-term interest rate, inflationary expectations and sanctions should have a positive effect on the long-term interest rate. The results in Table 1 indicate that the influence of all the variables conforms to the requirements of economic theory. It can therefore be concluded that this function is an acceptable representation of the long-term interest rate of South Africa.

\subsection{Statistical evaluation of the estimated function}

Since all the variables in the regression are stationary, the assumptions of classical regression analysis are fulfilled. Consequently standard diagnostic and other statistical tests can be used to evaluate this function statistically.

The adjusted R-squared $\left(\bar{R}^{2}\right)$ of 0.957736 indicates that 95.7736 per cent of the variation in the long-term interest rate is explained by the variation in the dependent variables, which is evidence of a very good fit. The F-statistic of 136.9639 indicates that the dependent variables are jointly significant in explaining the long-term interest rate. The Durban-Watson (DW) statistic of 1.969636 fails to reject the null hypothesis of no serial correlation. The tstatistics testing the significance of the individual coefficients indicate that all the coefficients are significantly different from zero, and should therefore be included in the function. Table 2 summarizes the results of the diagnostic tests performed on the function. 
Table 2 Diagnostic test results

\begin{tabular}{|l|c|c|c|}
\hline $\begin{array}{c}\text { Test performed } \\
\text { for }\end{array}$ & Test & Test-statistic & Probability \\
\hline Normality & Jarque-Bera & 0.367785 & 0.832025 \\
\hline Heteroscedasticity & ARCH & 0.005304 & 0.941945 \\
& White & 8.983760 & 0.774169 \\
\hline Serial correlation & Breuch-Godfrey & 2.424835 & 0.297477 \\
& LM & & 0.210456 \\
\hline Specification & Ramsey Reset & 1.648535 & \\
\hline Parameter & CUSUM & Stable & \\
stability & CUSUM & Stable & \\
\hline
\end{tabular}

These diagnostic tests proved that

i) the error terms are normally distributed

ii) there is no heteroscedasticity present in the error terms

iii) there is no serial correlation in the error terms

iv) no variables have been omitted, and the specification of the functional form is correct

v) the parameters are stable

\subsection{Dynamic simulation}

To obtain an indication of the goodness of fit of the model, an initial dynamic simulation was performed. A graphical representation of the actual and simulated values for the derived equation provides a good indication whether the function is a good representation of the true data-generating process. The close correlation between the actual and simulated values of the long-term interest rate (see Figure 2) suggests that the function is a good representation of the true datagenerating process. 
Figure 2 Actual and simulated values of the long-term interest rate

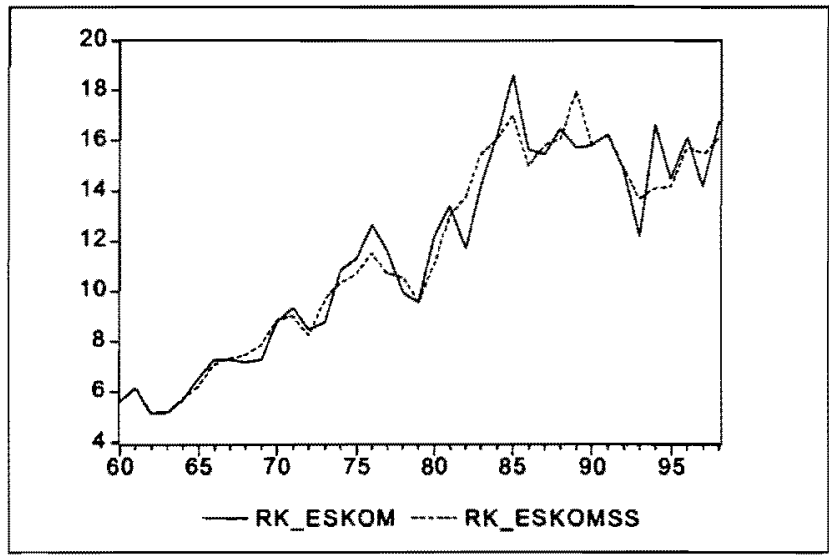

The model was subsequently subjected to two different types of shocks. In the first place the sensitivity of the model was tested by increasing the explanatory variables by 10 per cent. If the model is stable, these shocks should result in consistent long-run elasticity effects. This means that the simulated value must increase by 10 per cent of the original coefficient when one of the long-run explanatory variables is shocked by 10 per cent. When one of the short-term explanatory variables is increased, there should be an initial movement away from the long-run equilibrium path, but eventually the model should return to the original equilibrium path. The dynamics of the model are driven by the short-term interest rate and the sanction dummy, and they are the only variables giving dynamic feedback. In the second place, the stability of the model was tested by shocking each of the variables only in one period to test how long the system takes to retum to equilibrium. The effect of the sensitivity and stability shocks on the US rate are illustrated in Figures 3 and 4. Although now shown here, similar shocks were performed on all the other explanatory variables, and all of them illustrated that the function is stable. 
Figure 3 Difference between shocked and original simulated interest rates when a stability test is performed on the US interest rate

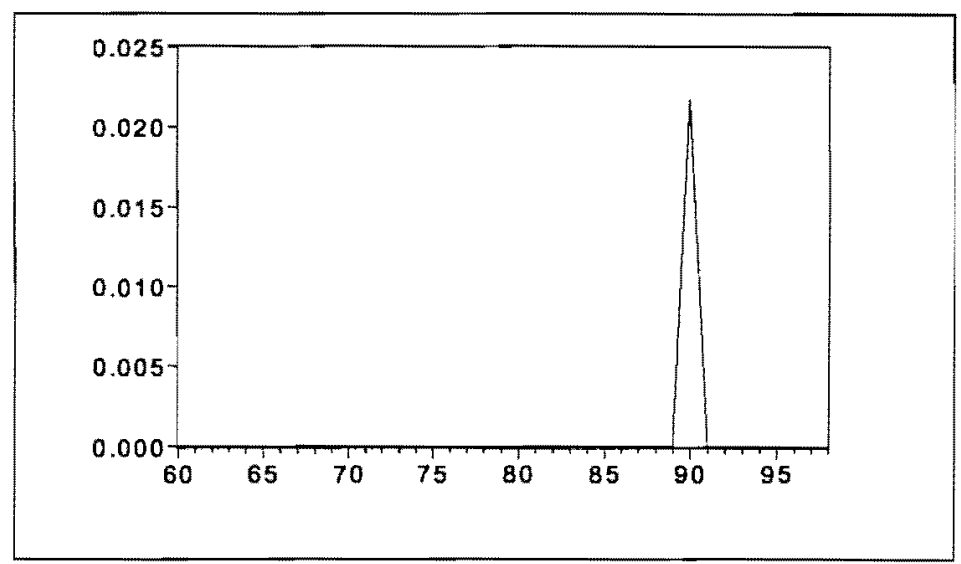

As may be seen from the graph, the difference between the initial and shocked simulations disappears almost immediately. This means that the effect of a shock will not persist, and that the model is therefore extremely stable.

A typical sensitivity test shocks the explanatory variables in the model, one at a time, by increasing them by 10 per cent. The shocks in the long-run variables must result in a convergence of the dependent variable on 10 per cent of the estimated coefficient of the shocked variable - in other words 10 per cent of the elasticity effect. A shock in the short-run variables, however, must result in an initial shock, after which the dependent variable must converge on the original equilibrium path. The first shock was performed on the US long-term rate, by increasing it by 10 per cent from 1967. The difference between the original and shocked simulations is illustrated in Figure 4. The shock results in an immediate movement away from the long-run equilibrium path to a new equilibrium path. The difference between the original and shocked simulations is 10 per cent of the coefficient of the US interest rate, which is consistent with the elasticity effect. Although not shown here, similar shocks were performed on all the other explanatory variables, and they all indicated that the function is stable. 
Figure 4 Difference between shocked and original simulated interest rates when a sensitivity test is performed on the US long-term interest rate

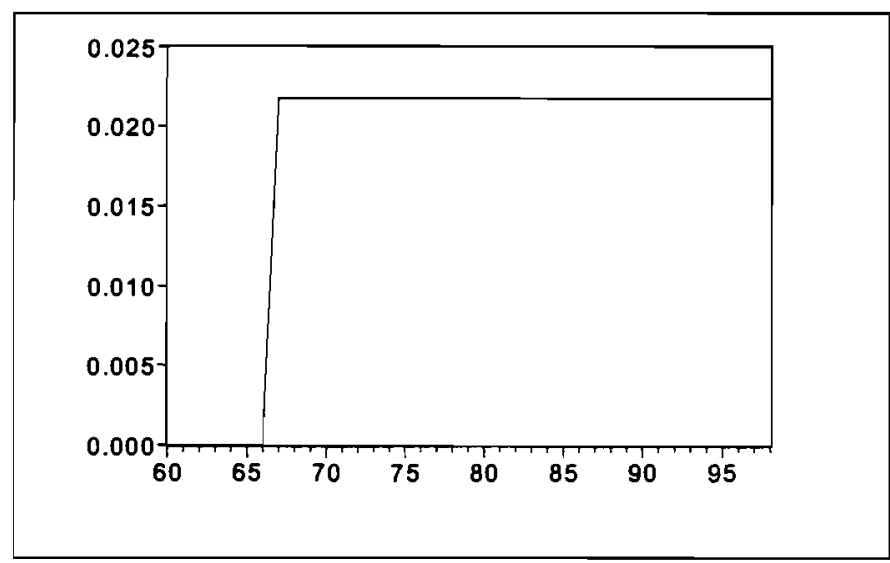

The function has passed economic and statistical evaluation and can therefore be regarded as a true representation of the determination of the South African longterm interest rate. The results showed that the long-term interest rate is mainly determined by inflationary expectations, but that the US long-term rate and the domestic short-term rate also have important influences on the long-term rate. Interest rates increased significantly during the sanction era, which shows that South Africa is extremely vulnerable to international sentiment. These results have important policy implications, which are discussed in the next section.

\section{THE EFFECT ON MONETARY POLICY}

Monetary policy makers want to know whether and to what extent they are able to influence long-term interest rates, and which instruments they should use. The results of the empirical estimation indicate that the South African long-term interest rate reacts mainly to changes in international interest rates, the shortterm interest rate and inflationary expectations. This has several important policy implications.

The South African Reserve Bank plays a vital role in determining the level of short-term interest rates, because they are closely related to the rates at which the Bank lends money to private sector banks (SARB, 1999). Since the empirical results showed that the long-term interest rate reacts to changes in the short-term interest rate, monetary authorities can influence the long-term rate by 
changing the short-term rate. However, the influence of the Reserve Bank on the long-term interest rate through changes in the short-term interest rate is limited. Owing to financial globalisation, the monetary authorities in a small open economy such as that of South Africa cannot force interest rates, especially long-term interest rates, in a direction other than that dictated by the markets. If the monetary authorities try to do that, investors and borrowers simply go to other countries with competitive opportunities.

The influence of the US rate is almost as great as the influence of the domestic short-term rate. This means that, as in other small open economies, the South African long-term rate is extremely sensitive to movements in international markets. This emphasises the fact that the South African capital market is not a price leader but a price follower, and that the authorities cannot force domestic interest rates in a direction other than that dictated by the markets. The upward pressure on interest rates during the sanctions era also emphasises the sensitivity of South African interest rates to international sentiment.

The empirical results indicated that the influence of inflationary expectations is far greater than that of the short-term or foreign interest rates. This shows that the monetary authorities can have a greater effect on the long-term interest rate if they can influence inflationary expectations. As part of a new approach to monetary policy and price stabilisation, the government and the Reserve Bank announced an inflation target band in February 2000. The inflation-targeting framework does not require significant changes in monetary policy, but the aim is to reduce the inflationary expectations of consumers, producers, employers and workers (RSA, 2000: 3). The experiences of other countries that adopted inflation targets show that this increases stability in nominal interest rates. The results of this study show that nominal interest rates in South Africa will also be stabilised if the monetary authorities can convince the public that the inflation target will be reached.

The monetary authorities can influence the long-term interest rate by changing the short-term interest rate and inflationary expectations. The influence of inflationary expectations on the long-term interest rate is greater than that of the short-term interest rate, and therefore the recently introduced inflation-targeting framework can have a significant impact on the long-term interest rate if it reduces inflationary expectations. As in other small open economies, the South African interest rate is sensitive to changes in international interest rates and therefore the monetary authorities cannot force interest rates in a direction other than that which the markets dictate. 


\section{CONCLUSION}

A market-related approach was followed in this study to explain the determination of long-term interest rate in South Africa. Apart from the theoretical factors, the political and economic environment in which interest rates are determined plays a key role in the process of interest rate determination.

Broadly put, since the 1960 s South African monetary policy may be divided into the pre-1985 and post-1985 periods with the shift from the use of direct monetary instruments to market-oriented monetary policy. This shift was in line with the global shift in the 1980 s to market-oriented policy, and was encouraged by the liberalisation of international financial markets.

The most significant socio-political events that impacted on the course of South African interest rates were the intemational sanctions during the $1980 \mathrm{~s}$, and the process of financial globalisation during the $1990 \mathrm{~s}$. The sanctions period was characterised by high interest rates in the attempt to prevent capital outflow and attract foreign capital. Owing to financial globalisation, international financial interdependence has increased substantially, and also become more volatile and subject to speculation.

The factors that influence the South African long-term interest rate and the magnitudes of these influences were empirically estimated on the basis of a market-related approach, with annual data from 1960 to 1998. The results indicated that there was a structural break in the long-term interest rate in 1985 when monetary policy in South Africa changed, in line with the rest of the world, from direct to market-oriented policy. The long-term interest rate is determined by the US long-term rate, the domestic short-term rate and inflationary expectations, of which inflationary expectations have the greatest influence. This means that the monetary authorities can affect long-term interest rates by either changing short-term interest rates or influencing inflationary expectations, but they cannot force interest rates in a direction other than that indicated by the markets because domestic rates are sensitive to changes in international markets. 


\section{APPENDIX 1}

\section{Graphical representation of data series employed in estimations}
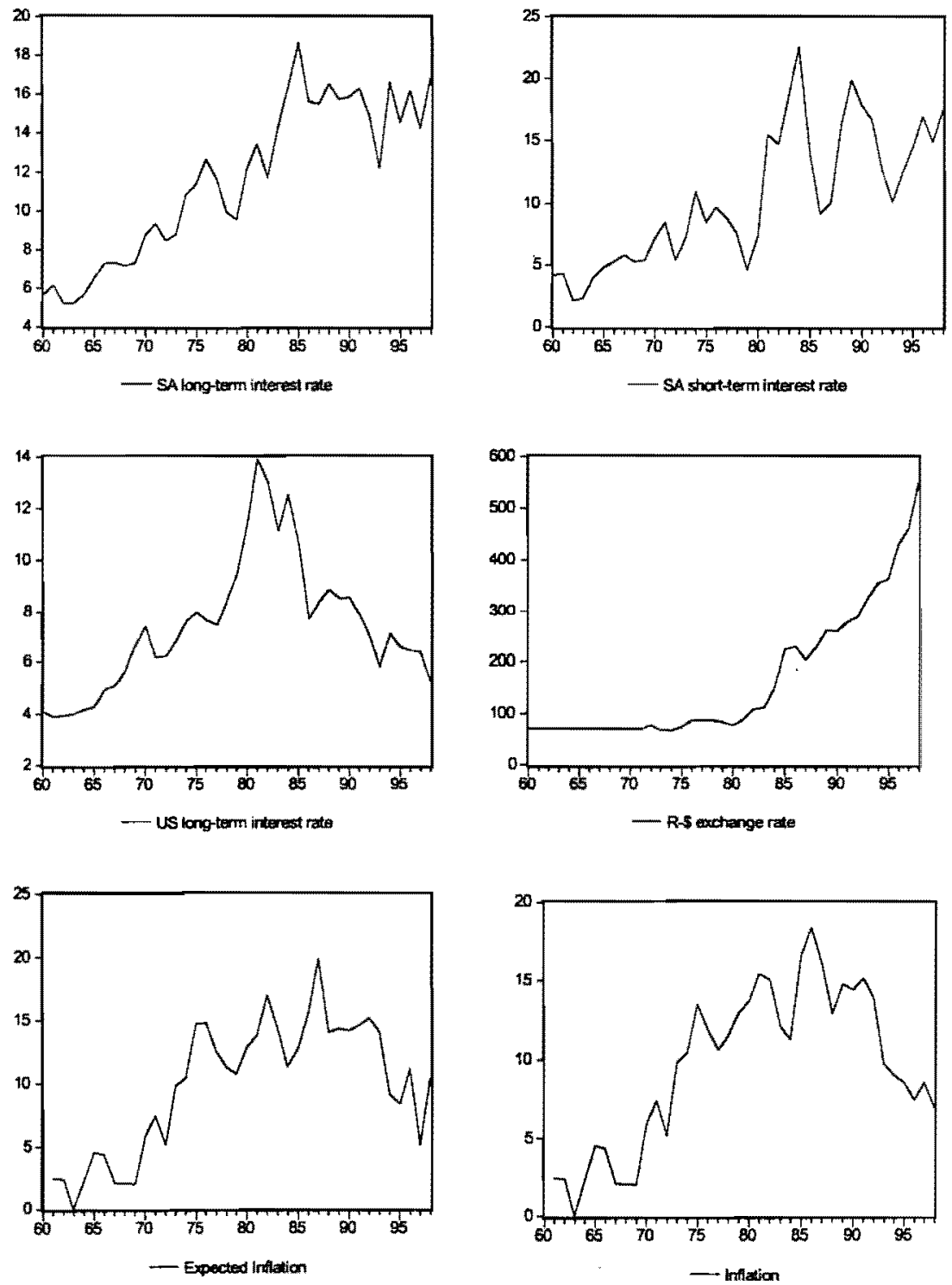


\section{APPENDLX 2}

\section{List of variables}

\begin{tabular}{|l|l|}
\hline Series & Description \\
\hline RL & Nominal SA long-term interest rate (Eskom rate) \\
\hline US & $\begin{array}{l}\text { Nominal rate of US long-term govermment bonds } \\
\text { acceptance rate) }\end{array}$ \\
\hline RS & $\begin{array}{l}\text { Dummy created to represent years of sanctions and } \\
\text { disinvestment actions against South Africa }\end{array}$ \\
\hline DUM-SANCT & $\begin{array}{l}\text { Kalman filter prediction of expected one-period-ahead } \\
\text { consumer price level }\end{array}$ \\
\hline E(INFL) & Dummy for the new trend since structural break in 1985 \\
\hline DT & Trend \\
\hline TIME &
\end{tabular}

\section{APPENDIX 3}

Order of integration

Table A Augmented Dickey-Fuller and Phillips-Perron tests for nonstationarity, levels, 1960-1998 (all data series in natural logarithmic form)

\begin{tabular}{|l|l|l|l|l|l|}
\hline Series & Model & Lags $^{1}$ & $\tau_{\tau,} \tau_{u,} \tau$ & $\phi_{3,}, \phi_{1}$ & PP $^{2}$ \\
\hline RS & Trend & 1 & $-4.196^{* *}$ & $5.98^{* * *}$ & $-3.190^{*}$ \\
& Constant & 4 & -1.76 & 3.166 & -1.540 \\
& None & 4 & 1.23 & 2.57 & 0.4968 \\
\hline
\end{tabular}

* Significant at a $10 \%$ level

** Significant at a 5\% level

*** Significant at a $1 \%$ level

Table B Augmented Dickey-Fuller and Phillips-Perron Tests for nonstationarity, first differenced, 1960-1998 (all series in natural logarithmic form)

\begin{tabular}{|l|l|l|l|l|l|}
\hline Series & Model & Lags & $\tau_{\mathrm{r}}, \tau_{\mu,} \tau$ & $\phi_{3}, \phi_{1}$ & PP \\
\hline E(INFL) & Trend & 3 & 0.4366 & 2.11 & -0.606 \\
& Constant & 0 & -1.66 & 2.78 & -1.570 \\
& None & 0 & -0.427 & & -0.316 \\
\hline
\end{tabular}

* Significant at a $10 \%$ level

* Significant at a $5 \%$ level

*** Significant at a $1 \%$ level 
Table C Perron Test ${ }^{3}$ for non-stationarity in the presence of a structural break ${ }^{4}$, levels, 1960-1998 (all data series in natural logarithmic form)

\begin{tabular}{|l|l|l|l|l|l|l|l|l|}
\hline Series & $\mathbf{T}_{\mathbf{B}}$ & $\lambda$ & $\mathbf{K}$ & $\begin{array}{l}\tilde{\mu} \\
\left(\mathrm{t}_{\tilde{\mu}}\right)\end{array}$ & $\begin{array}{l}\widetilde{\beta} \\
\left(\mathrm{t}_{\bar{\beta}}\right)\end{array}$ & $\begin{array}{l}\tilde{\gamma} \\
\left(t_{\tilde{\gamma}}\right)\end{array}$ & $\begin{array}{l}\tilde{\alpha}^{5} \\
\left(t_{\tilde{\mu}}\right)\end{array}$ & $\mathbf{T}(\tilde{\alpha}-1)$ \\
\hline RL & 1985 & 0.64 & 0 & $\begin{array}{l}-84.899 \\
(-18.14)\end{array}$ & $\begin{array}{l}0.04416 \\
(18.63)\end{array}$ & $\begin{array}{l}-0.0475 \\
(-7.028)\end{array}$ & $\begin{array}{l}0.21614 \\
\left(-4.85^{* *}\right)\end{array}$ & $-30.57^{*}$ \\
\hline US & $1985^{6}$ & $0.7^{\prime}$ & 3 & $\begin{array}{l}-85.663 \\
(-18.66)\end{array}$ & $\begin{array}{l}0.04439 \\
(19.07)\end{array}$ & $\begin{array}{l}-0.1069 \\
(-13.69)\end{array}$ & $\begin{array}{l}0.27123 \\
\left(-3.93^{*}\right)\end{array}$ & $-32.79^{*}$ \\
\hline $\begin{array}{l}\text { E } \\
\text { (INFL) }\end{array}$ & 1985 & 0.64 & 0 & $\begin{array}{llll}-12.419 \\
(-14.42)\end{array}$ & $\begin{array}{l}0.00633 \\
(14.52)\end{array}$ & $\begin{array}{l}-0.0129 \\
(-10.71)\end{array}$ & $\begin{array}{l}0.17428 \\
\left(-4.78^{* *}\right)\end{array}$ & $-32.20^{*}$ \\
\hline
\end{tabular}

* Significant at a $5 \%$ level

** Significant at a $1 \%$ level

\section{ENDNOTES}

1 The number of lags used in the estimated equations was determined according to the method suggested by Said and Dickey (1984), which means starting with $T^{1 / 3}$ lags and using sequential t-tests to exclude the last lag if insignificant.

2 The number of truncation lags used in the Bartlett kernel was determined as suggested by Newey-West. For this sample size Newey-West suggested 3.

3 The version that tests $\mathrm{H}_{0}: \mathrm{y}_{t}=\mu_{t}+\mathrm{y}_{\mathrm{t}-1}+\left(\mu_{2}-\mu_{1}\right) D U_{t}+\varepsilon_{\mathrm{t}}$ against $\mathrm{H}_{\mathrm{a}}$ : $y_{t}=\mu+\beta_{1} t+\left(\beta_{2}-\beta_{1}\right) D T_{t}^{*}+\varepsilon_{t}$, where $D U_{t}=1$ if $D T_{B}$ and 0 otherwise and $\mathrm{DT}_{t}^{*}=t$ if $>\mathrm{T}_{B}$ and 0 otherwise, was used.

4 The parameters given are from the model:

$$
y_{t}=\mu+\beta t+\gamma D T^{*}{ }_{t}+y_{t} ; y_{t}=\alpha y_{t-1}+\sum_{i=1}^{k} c_{i} \Delta y_{t-i}+\varepsilon_{t}
$$

$5 \quad$ Phillips and Ouliaris (1990) showed that $t$ ratio procedures diverge under that alternative at a slower rate than direct coefficient tests, which means that direct coefficient tests should have superior power properties over $t$ ratio tests. Therefore the T( $\alpha-1)$ test might have higher power than the $\alpha$ test and therefore both are reported. However, in this study they gave the same results.

6 Visual inspection of the data suggests a possible structural break in 1981, and the Perron test confirmed this by rejecting the null hypothesis of a unit root against the alternative of trend stationarity with a structural break in 1981. However, to keep the specification parsimonious, the Perron test was also conducted to test the null of a unit root against the alternative of 
trend stationarity with a structural break in 1985.

7 Data from 1954 to 1998 were used to test the stationarity of the US interest rate.

\section{REFERENCES}

1 AWAD, M.A. \& GOODWIN, B.K. (1998) "Dynamic Linkages Among Real Interest Rates In Reply to: International Capital Markets", Journal of International Money and Finance, 17: 881-907.

2 BOTHA, D.J.J. (1997) "The South African Reserve Bank and the Rate of Interest", South African Journal of Economics, 65: 532-67.

3 CHAREMZA, W.W. \& DEADMAN D.F. (1997) New Directions in Econometric Practice: General to Specific Modelling, Cointegration and Vector Autoregression, Hampshire: Elgar.

4 DICKEY, D. A \& Fuller, W.A. (1979) "Distribution of the Estimators for Autoregressive Time Series with a Unit Root", Joumal of the American Statistical Association, 74: 427-31.

5 ENDERS, W. (1995) Applied Econometric Time Series, New York: John Wiley \& Sons Inc.

6 FABOZZI, F.J. (1992) Active Asset Allocation: State-of-the-Art Portfolio Policies, Strategies and Tactics, Chicago: Probus Pub. Co.

7 FABOZZI, F.J. (1995) Investment Management, New Jersey: Prentice Hall, Inc.

8 FABOZZI, F.J. \& MODIGLIANI, F. (1996) Capital Markets: Institutions and Instruments, London: Prentice Hall, Inc.

9 FAURE, A.P.; FALKENA, H.B; KOK, W.J. \& RAINE, G.E. (1991) The Interest-Bearing Securities Market, Halfway House: Southern Book Publishers (Pty) Ltd.

10 FOURIE, L.J., FALKENA, H.B. \& KOK, W.J. (1992) Fundamentals of the South African Financial System, Halfway House: Southern Book Publishers.

11 FOURIE, L.J., FALKENA, H.B. \& KOK, W.J. (1999) Student Guide to the South African Financial System, Cape Town: Oxford University Press.

12 GAYED, M.E.S. (1990) Intermarket Analysis and Investing: Integrating Economic, Fundamental and Technical Trends, New York: New York Institute of Finance.

13 HANDLEY, A. \& MILLS, G. (1996) The South African Economy in the $1990 s$, Johannesburg: South African Institute of International Affairs.

14 HARMSE, C. \& DU TOIT, C.B. (1999) "An Empirical Capital Market Rate Function for an Emerging Market Economy", South African Journal of Economic and Management Sciences, 2: 335-57. 
15 HODGSON, A., KREMMER, M.L. \& LEE, S. (1998) "Endogenous and Exogenous Determinants of Interest Rates", Journal of Multinational Financial Managament, 8: 249-63.

16 KOEKEMOER, R. (2000) "Private Consumption Expenditure in South Africa: The Role of Price Expectations and Learning", Unpublished Doctoral Thesis. Pretoria: University of Pretoria.

17 MEHRA, Y.P. (1994) "An Error-Correction Model of the Long-Term Bond Rate, Economic Quarterly 80: 49-69.

18 MEHRA, Y.P. (1995) "Some Key Empirical Determinants of Short-Term Nominal Interest Rates", Economic Quarterly, 81: 33-52.

19 MURPHY, J.J. (1991) Intermarket Technical Analysis: Trading Strategies for the Global Stock, Bond, Commodity, and Currency Markets, Toronto: John Wiley \& Sons Inc.

20 PAIN, D. \& THOMAS, R. (1997) Real Interest Rate Linkages: Testing for Common Trends and Cycles, London: Bank of England.

21 PERRON, P. (1989) "The Great Crash, the Oil Price Shock, and the Unit Root Hypothesis", Econometrica, 57: 1361-402.

22 PHILLIPS, P.C.B. \& PERRON, P. (1988) "Testing for a Unit Root in Time Series Regression", Biometrika, 75: 335-46.

23 PHILLIPS, P.C.B. \& OULIARIS, S. (1990) "Asymptotic Properties of Residual Based Tests for Cointegration", Econometrica, 58: 165-93.

24 REPUBLIC OF SOUTH AFRICA (RSA) (2000) Budget Review 2000, Pretoria: Government Printer.

25 SAID, S.E. \& DICKEY, D.A. (1984) "Testing for Unit Roots in Autoregressive-Moving Average Models with Unknown Order", Biometrika, 71: 599-607.

26 SMITH, S.S. \& SPUDICK, R.E. (1993) Interest Rates - Principles and Applications, Harcourt Brace Jovanovich: The Dryden Press.

27 SOUTH AFRICAN RESERVE BANK (SARB) (1999) Fact Sheet No. 8: Interest Rates and How They Work, Pretoria: South African Reserve Bank.

28 STALS, C. (1999) The Influence of International Financial Crises on the South African Economy, Address at the $52^{\text {nd }}$ Congress of the South African Nurserymen's Association on 17 May 2000.

29 STAPELBERG, N.H. (1981) Die Finansiële Struktuur van Suid-Afrika. Pretoria: N.H.S. Uitgewers.

30 TRAN, D.T. \& SAWHNEY, B.L., (1988) "Government Deficits, Capital Flows and Interest Rates" Applied Economics, 20: 753-65. 